\title{
Doctors with two (or more) hats
}

\author{
Doctors of Another Calling: Physicians \\ Who Are Best Known in Fields Other \\ than Medicine \\ David K.C. Cooper, editor \\ University of Delaware Press; 2013
}

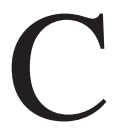
an one person wear two hats and be successful? Doctors of Another Calling, a delightful collection of profiles by 25 different authors, explores this question. Although most of the authors are American, the subjects are geographically diverse, including countries such as Afghanistan, China, Cuba and France. There are no Canadians; however, all the authors say they were influenced by Canada's own Dr. William Osler through the American Osler Society. The majority of the doctors featured in this book lived long before the era of specialization or of women practising medicine, but in Appendix 2 you will find a wealth of information hinting at future volumes as the medical profession evolves.

It is amazing what some of these docs got into: piracy, politics, poetry and more. Did you know that Armand Hammer, the multimillionaire philanthropist, had a medical degree? There's much to choose from, but here are a few samples to whet your appetite.

\section{Food}

Dr. John Kellogg (1852-1943), a vegetarian from Battle Creek, Michigan, believed in a natural approach to health and wanted a fast, frugal and tasty meal. He and his brother started experimenting and developed Kellogg cereals. Kellogg's formula for success was "a desire to be in control, a knack for publicity, and an immense capacity for work," a recurrent theme in this book.

\section{Books}

What physician/writer/knight has the epitaph, "Steel true, blade straight"?

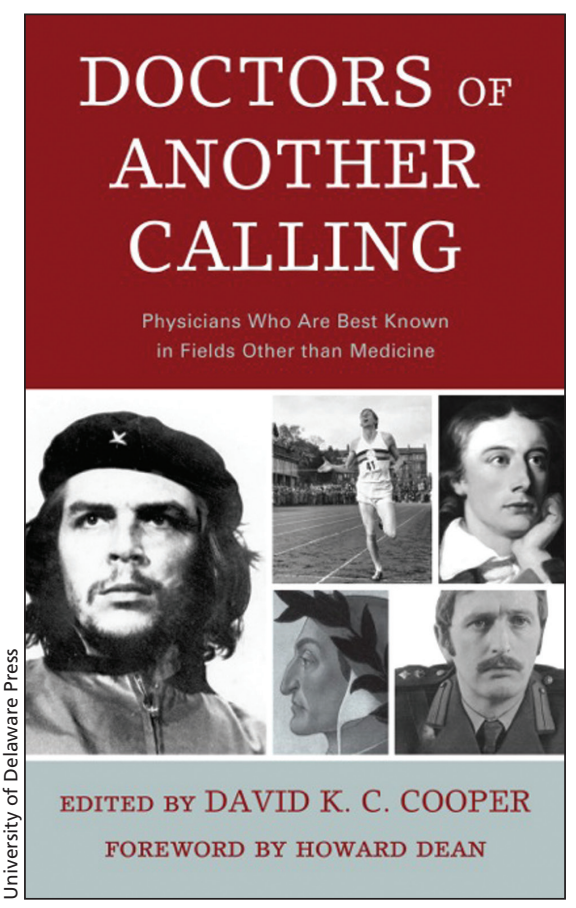

Here's a clue: when this physician realized he was using his literary income to support his medical office, he abandoned medicine and became a celebrity author. (For those of you still wondering, it's Sir Arthur Conan Doyle [1859-1930].)

Another physician-author profiled in this book offers a slight variation on Doyle's story. His initial medical practice was challenging and professionally fulfilling but not lucrative, so he headed to London and became affluent treating hypochondriacs. Money did not bring happiness, but retirement to rural Scotland did. He went on to become the J.K. Rowling of his day. (We're talking about well-known novelist A.J. Cronin [1896-1981].)

Also profiled are doctors who simultaneously nurtured medical and writing careers, drawing inspiration from one and creative release from the other. Drs. Anton Chekhov (1860-1904) and Abraham Verghese (b. 1955) have both achieved this rare status.

\section{Polymaths}

Captain Hook "is not wholly evil - he has a Thesaurus in his cabin." You can guess who penned this wonderful whimsy (J.M. Barrie [1863-1937]), but do you recognize the physician who is hiding in this sentence (or at least in the cabin)? This doctor was a polymath who made notable contributions in a number of callings, including medicine. (If you haven't guessed, we're talking about Peter Mark Roget [1779-1869] who is best known for publishing, in 1852, the Thesaurus of English Words and Phrases.)

\section{Comedy}

The editor of this collection, Dr. David Cooper, wears multiple hats too: surgeon, editor and writer. He pens a very compelling portrayal of the humorist Dr. Graham Chapman (1941-1989). Chapman qualified in medicine, but his comedic talents won the day and he became a brilliant member of the British comedic troupe, Monty Python's Flying Circus, described by Cooper as "the most influential comedy series in British television history."

Cooper's profile of Chapman foreshadows Chapman's future as an adult:

It was after games with the local rugby football club that Chapman was first introduced to alcohol, on which he gradually became more dependent.

While at Cambridge, Chapman teamed up with John Cleese, the United Kingdom's pre-eminent comedian. The latter provided ideas that Chapman then elevated "to unexpected absurd levels." An example of this collaboration is Cleese's idea of returning an item to a shop, which Chapman took to its incongruous apogee with the "Dead Parrot Sketch."

Chapman died of esophageal cancer at an early age. At his funeral, his colleagues sang, "Always Look on the 
Bright Side of Life." Cooper concludes that Chapman, as a writer and actor, brought more joy and laughter to people than he ever could have as a doctor and, after all, laughter is the best medicine.

\section{The dentist}

As a nod to inclusivity, this collection also contains an article about North America's most famous dentist who achieved his fame as a gambler and gunman: John Henry "Doc" Holliday (1851-1887). The author of this pro- file, Dr. Sandra Moss, sums up Doc's crowning achievement:

The events at the O.K. Corral boiled down to a lethal mixture of simmering feuds, shifting loyalties, secret deals, alcohol, misplaced trust, misread signals, sociopathic personalities, and testosterone.

You will find a lot of testosterone in this collection, although there is some estrogen plus a sprinkling of the ingredients mentioned above. The difference between Doc Holliday and the medical doctors featured in Doctors of Another Calling, is that the latter, for the most part, have left a positive legacy that goes beyond their professional training to reach a much larger audience. As a part of this audience, you will be informed, entertained and inspired by their stories.

\section{Ian A. Cameron MD}

Rural physician

Sherbrooke, NS

CMAJ 2015. DOI:10.1503/cmaj.140182 